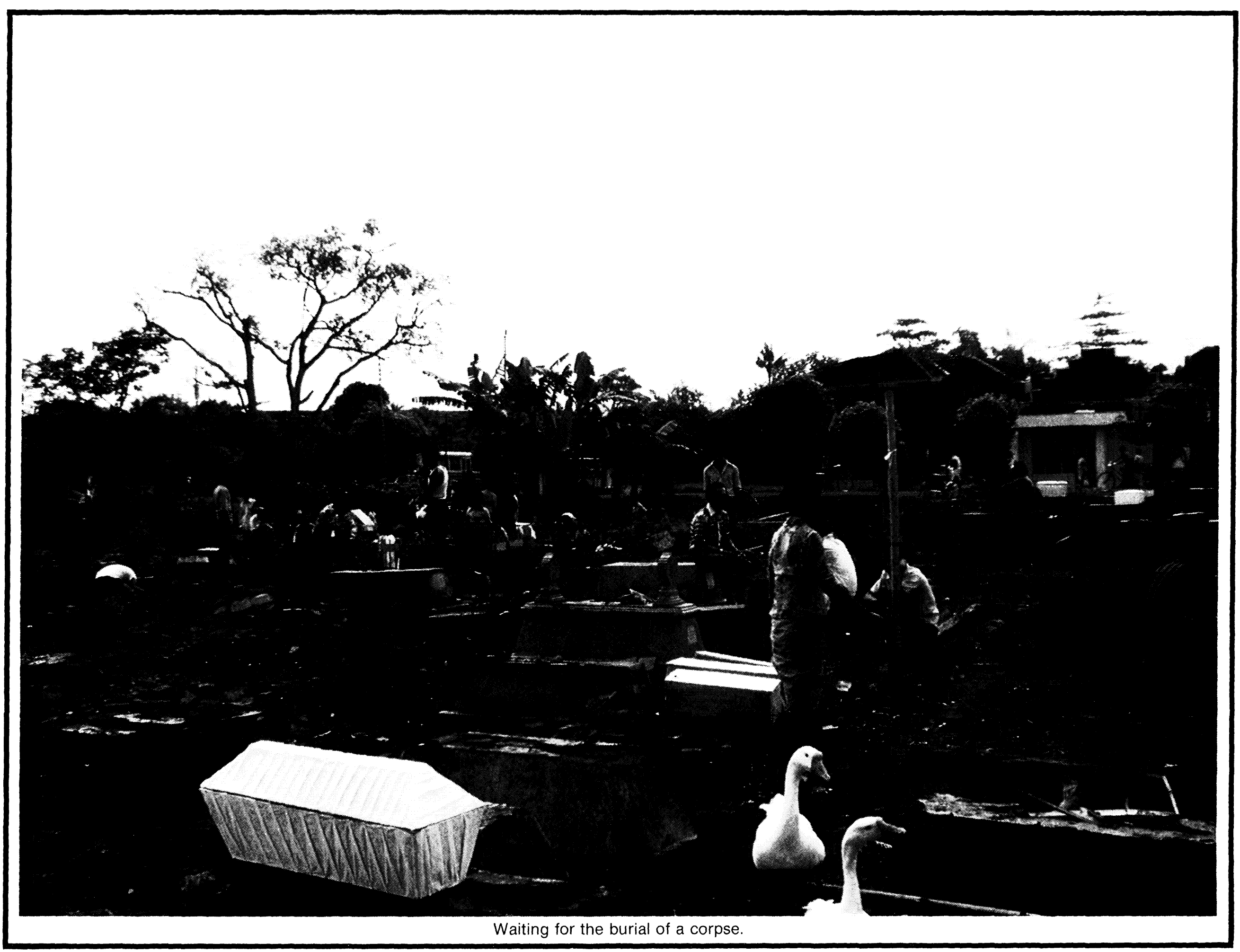





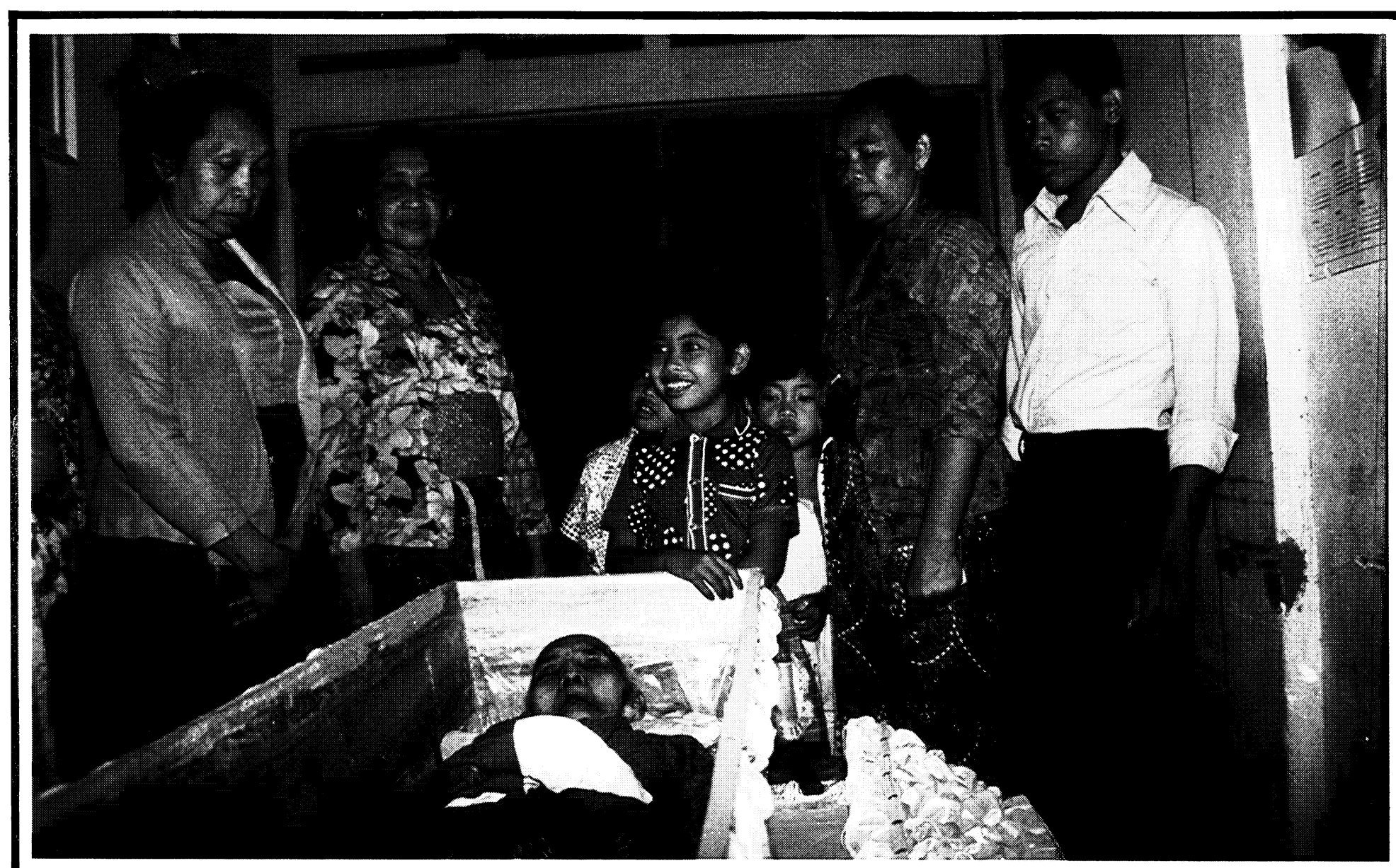

Neighbors (unrelated) posing with a new corpse.
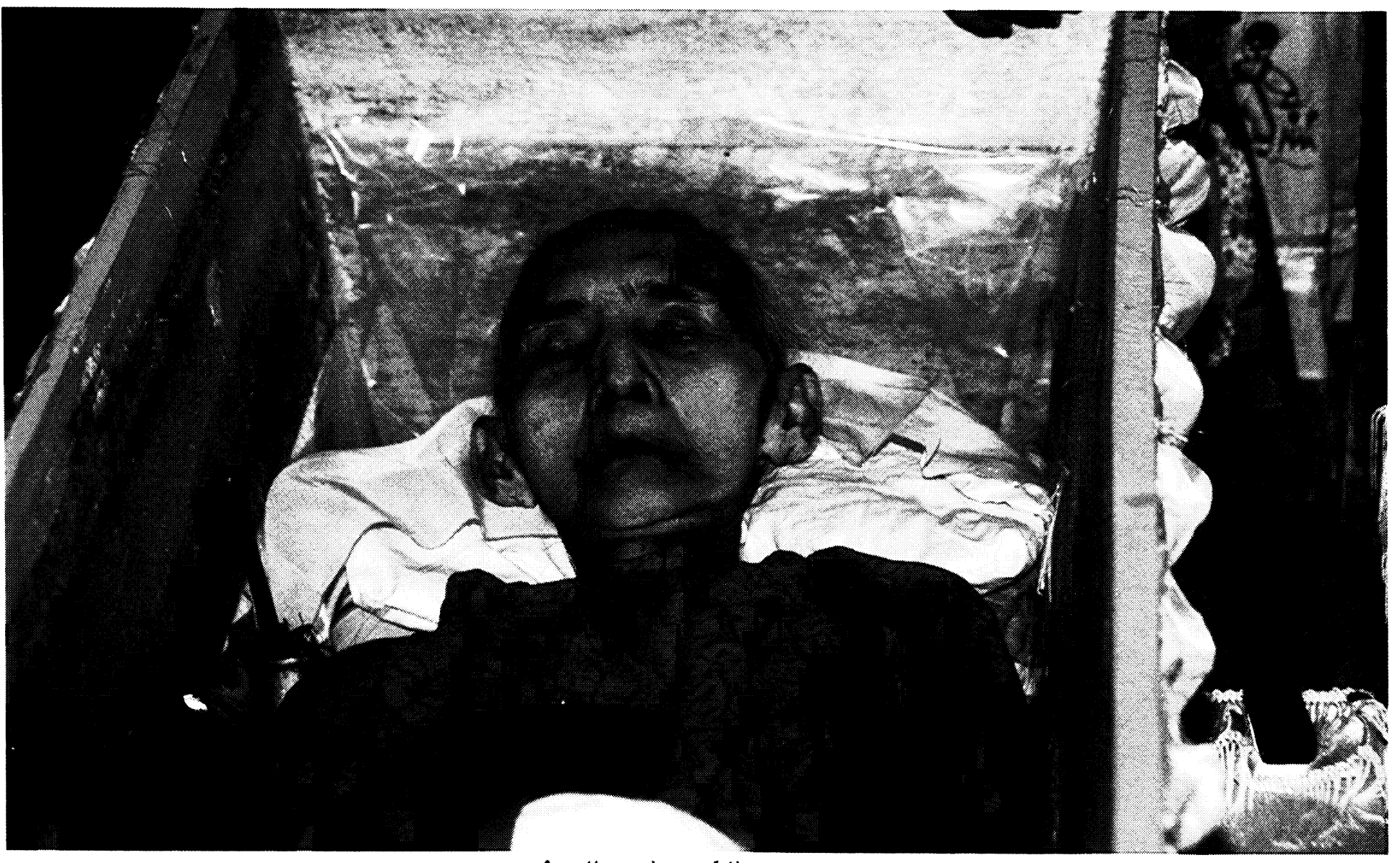



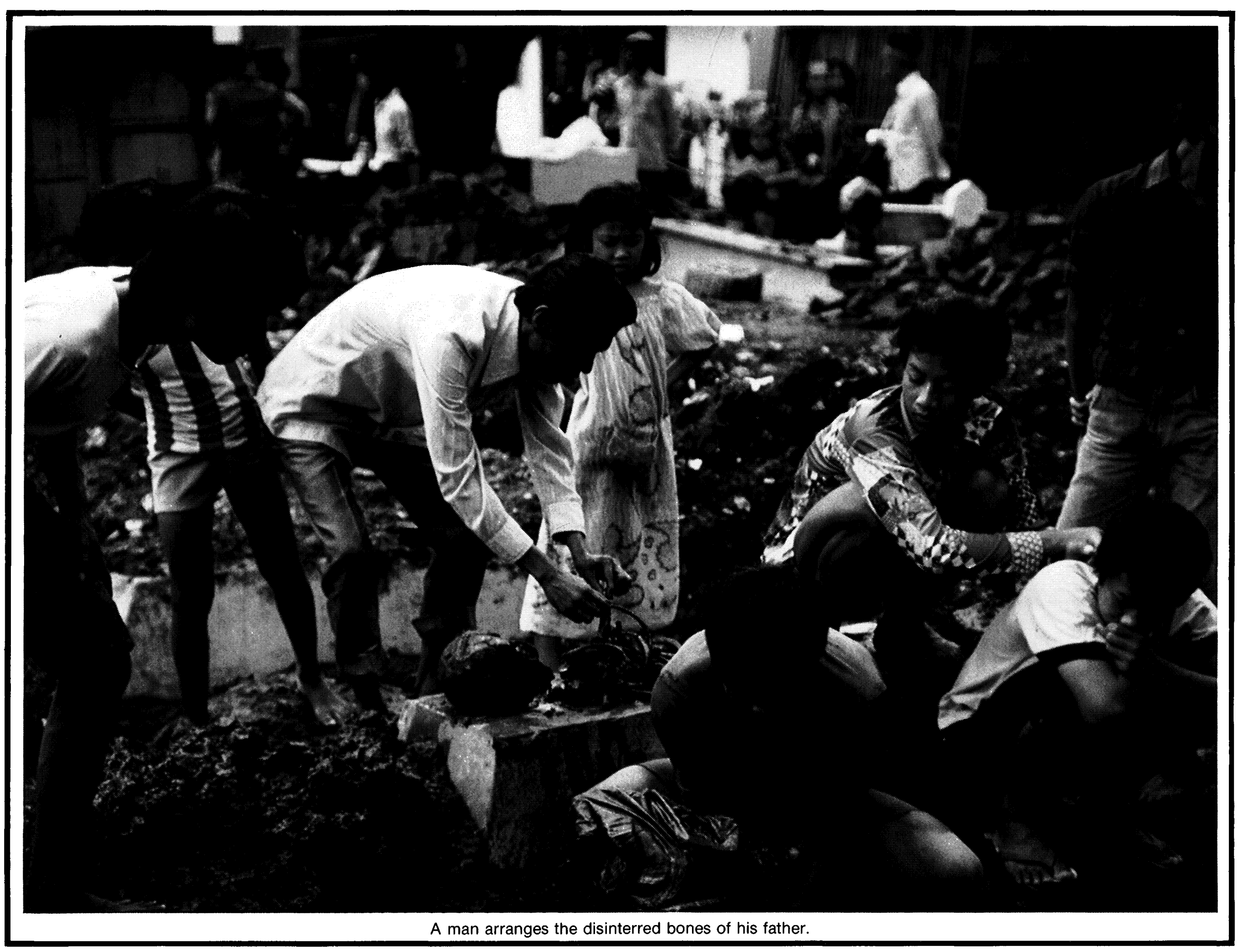





\title{
IMAGES AND ODORS IN JAVANESE PRACTICES SURROUNDING DEATH
}

\author{
James T. Siegel
}

A person is dead when he has been given up for dead by those closest to him. In Solo, ${ }^{1}$ as in other parts of Java, the time between biological and cultural death is short: sometimes even minutes. I was present when a man in his fifties was brought the news of his mother's death. He shed one tear and after that was able to act as he would on ordinary occasions. One seldom sees expressions of grief or mourning. ${ }^{2}$ It is common at funerals to be greeted, for instance, by a widower who shows no sign of bereavement though his wife may have died less than a day before. Clifford Geertz has described the atmosphere at funerals:

The mood of a Javanese funeral is not one of hysterical bereavement, unrestrained sobbing, or even of formalized cries of grief for the deceased's departure. Rather, it is a calm, undemonstrative, almost languid letting go. Tears are not approved of and certainly not encouraged; the effort is to get the job done, not to linger over the pleasure of grief . . . the funeral and postfuneral ritual is said to produce a feeling of iklas, a kind of willed affectlessness, a detached and static state of "not caring." . . .

1. I spent the summers of 1978 and 1979 in Surakarta (also called Solo) mainly learning Javanese. I am grateful to the Cornell Southeast Asia Program for funding part of my expenses during this time. I was enabled to live in Surakarta from September 1980 through 1981 thanks to Guggenheim Foundation and Fulbright Hays grants supplemented by funds from the Social Science Research Council and the Cornell Southeast Asia Program. An abbreviated version of this paper was given at the Indonesian Studies Summer Institute at the University of Ohio in August 1982. It is difficult for any ethnographer of Java to claim that what he has observed obtains for Javanese speakers throughout the island. In regard to practices surrounding death I have found no contrary evidence in other ethnographies and much that is similar. Still, since many fundamental matters vary greatly between Surakarta and the countryside surrounding it, I can only be sure that what I say applies to Surakarta.

2. I attended twenty-two funerals and saw expressions of grief only on the occasions I note later in the paper. I was present shortly after deaths had occurred in three of the families. In one case, I was there minutes after the death; in another, within a couple of hours. In several other cases, I had ample opportunity to see if family members grieved in the months after the death.

Javanese do not think grief is in itself shameful. It is disapproved of only if it disrupts others. On three occasions Javanese freely admitted their grief to me, which makes me feel that the many others who denied grieving, who said they were instantly "detached" or iklas, were accurate in their statements. Occasionally someone would report another state, bingung, or confusion, as their first reaction to learning of a death.

3. "Ritual and Social Change: A Javanese Example," in The Interpretation of 
Even the family members closest to the deceased often, perhaps usually, are iklas, "detached," within minutes after a death. ${ }^{4}$ How is this achieved and how is it maintained? I will focus on two bits of paraphernalia to find an answer: photographs and incense.

The funeral ceremony has been described elsewhere; briefly it consists of oratory, thanking the guests for their attendance and eulogies of the deceased in the highest possible Javanese. ${ }^{5}$ There are minor differences between ceremonies depending on the religion of the deceased. But a Christian funeral, a Muslim funeral, or the funeral of a nominally Muslim person are in general outline the same. After the oratory and prayers, the body is transported to the cemetery. There are further ceremonies three, seven, forty, a hundred, and a thousand days after the death, as well as ceremonies at the erection of the gravestone and on the first and sometimes second anniversaries of the death. The purpose of the ceremonies is to pray that the soul of the deceased be accepted by God.

For the ordinary guest at the ceremonies most time is spent waiting for the oratory to begin. There is quiet chatting but no special mood of piety. People talk about anything at all, not avoiding mention of the deceased and not changing their tone when they do so. The coffin is usually draped in white ruffled cloth and ornamented with flowers. An announcement that it is about to be brought out of the house is made over the loudspeaker; often the announcement includes an invitation to those who wish to take photos to come to the front.

The tone that is appropriate to everyday life is also appropriate at a funeral. Smiles are not out of place. Anyone who showed a special sense of the occasion would, in fact, be thought to be acting not quite properly. Such a person would be thought unable to control himself or herself, in which case it would be better if he/she were not to come. As I have said, there is no attempt to avoid mentioning the deceased as one chats. There is, however, very little in the way of sentiments regretting the death. One's death is thought to be in the hands of God: acceptance

Cultures (New York: Basic Books, 1973), p. 153. (The essay was originally published in 1959.)

4. There are two exceptions: young children, sometimes through their early teens., whose parents die, and mothers whose children die.

5. On this topic, see especially Clifford Geertz. The Religion of Java (Glencoe: Free Press, 1960), pp. 68ff. There are differences in detail between Geertz's description of ceremonies in rural East Java and what takes place in Solo: for instance, some Solonese Muslims do not consider the modin or Islamic religious functionary absolutely necessary to carry out the ritual of the funeral. However these differences do not figure in Solonese thinking about death. One can find manuals describing funerary customs such as R. Tanojo, Tata-tjaranipon Kasripahan (Surakarta: De Bliksem, 1933). I am indebted to John Pemberton for bringing this item to my attention. The people who come to a funeral include most of the deceased's acquaintances. It would be a solecism for neighbors and kin not to attend. One could expect also those with whom the person worked, members of his or her organizations and, in the case of prominent figures, those who knew of them. On this topic see Robert R. Jay, Javanese Villagers: Social Relations in Rural Modjokuto (Cambridge: MIT Press, 1969), pp. 220ff. One can expect amongst the speakers at least one or two figures of authority. In the case of someone from the palace, a palace official; in the case of someone local, the lurah and the head of the neighborhood. On the comfort these figures seem to bring to the deceased see Ward Keeler, "Father Puppeteer" (Ph.D. dissertation, University of Chicago, 1982), P. 162. 
of this fact is part of being iklas, detached. Possibly for the same reason there are few of the usual questions people in the West ask at a death, questions that betray the fear that they too could die: what did the deceased die of (frequently no one seems to know), and how old were they.

People give various reasons for their ability to become iklas. Ordinarily they say that it is God's will that the person died. "What comes from God must return to God and therefore one must be iklas," said one person. (This answer in my experience is the same for all Solonese, regardless of their religion.) They also say that the deceased is not really gone, he or she is only somewhere else; that, if the spirit (roh) were to see you upset, it would be upset. What one wants is the removal of the spirit, to send it on its way rather than to keep it in memory. Indeed, it is a mistake to speak of mourning in a Javanese funeral if this means working through memories of the deceased in order to put them to rest. The point of being iklas is that one is not affected by such memories; that this absence of affect is almost instantly attained and that it is in everybody's interest: the deceased, the deceased's close relatives, and those with whom the latter have social intercourse. There is an immediate idealization of the deceased, as though one has only certain limited memories of the person, and these are not burdened with the added thought that he or she is no longer here. The funeral orator often, for instance, gives the biography of the deceased. But there is no attempt in doing so to show his or her commonality with those who are left behind. For example, at the very large funeral of one woman who had been active in many organizations, the offices she held were enumerated, but there was no attempt to give the details of what she did in such a way that one would have felt her energy and realized one's loss. It was rather as if one were supposed to equate her with the titles she held.

Photographs serve the same function. Many families have albums of photographs of relatives' funerals, which include not merely pictures of the crowd and the speakers at the ceremony, but also of the corpse and of the coffin after it had been lowered into the grave. Ordinarily photographs of people we know stimulate recall: being taken at a particular moment in time, they seem to capture the person as he was when the picture was taken. Looking at the picture, one has the impression that, just before and just after it was taken, things were different, and we draw on our memories to fill out what we see. A photograph of a corpse, however, has a different effect. A body devoid of life remains as it is. Rather than being unique to the moment in which the picture was taken, the same condition of the body continues after the picture was taken. There seems to be nothing outside the picture; nothing more to the corpse than what is visible. The effect is one of immunity to changes of time. When that is the case, the person is no longer the person as experienced and held in memory but the person as 'dead,' that is, fixed. Javanese funeral photography thus operates against memory; it is the person as image, and not the person connected with memories of him, that survives.

When death arrives, it brings with it a view of the person that is intended to replace thoughts of him or her alive. The ornate quality of the eulogies is appropriate here. It was, in fact, during one such eulogy that my neighbor remarked to me on the extraordinary alus or refined quality of the speaker's language: "he has spoken a long time and said almost nothing" was his admiring comment. The stereotyped quality of the photographs of funerals are analogous to this high Javanese oratory. The stereotyping indicates that it is the static quality of the image that is desired, not the unique moment of a particular funeral. Death brings with it a degree of respect and an idealization of the deceased that he or she was unlikely to have gotten by birth or achievement.

Javanese say that they fear the 'dead.' Graveyards, indeed, are generally thought to be haunted. It is remarkable, then, that a new corpse is not an object 
to be feared. The corpse is generally laid out in the main room of the house. The youth of the neighborhood sit up with it through the night. People come to view it sometimes, but this is not an obligation. There is none of the feeling of solemnity in its presence that there is in the West and none of the feeling that one is paying one's last respects to someone one knew. This is because the corpse acts as a sign of death rather than as a reminder of the person as he was in life. The fear that can arise when for some reason a funeral's progress has been interrupted has been excellently described by Clifford Geertz. In his account, the corpse became rigid, making it necessary to cut off the clothes with a knife, "an unusual procedure which deeply disturbed everyone. . . ." 6 In the view we are proposing here, the cutting off of the clothes would be disturbing not only because of the novelty of the procedure, but because it emphasized the changing state of the corpse, which became a thing in its own right, not an image of death. Indeed, in Geertz's description the increasing nervousness corresponds to a sense of time out of control; the inability to proceed with the funeral is contrasted to the progressive change of state of the corpse, as though decay would not have occurred had the funeral taken its course. It is the fixity of the impression that is challenged by decay. Geertz's account allows us to see that, before photographs became common in Java, the corpse itself, in its presumed unchangingness, furnished the image, supplied, or perhaps merely supplemented, by photographs today.

Yet we still do not know how that sign achieves its special place; how it is that, seeing the corpse, people do not grieve. The almost instant detachment Javanese achieve, however, becomes understandable through that part of the funeral ceremony known as trobosan. Just after the coffin is taken out of the house, borne on the shoulders of pallbearers, it is held up for a moment. Younger relatives, usually children and young adults, circle in and out under the coffin. The word for this practice, trobosan, means "to penetrate" or "cut through." One man explained to me that it means "to cut holes" in the space beneath the coffin (Javanese have a word for defined space--longan or kolongan--referring not to the boundaries of the enclosure but to the space itself). By so doing, one positions oneself for blessings (pangèstu) from the dead. This is considered a transitional moment for these younger people. It is the one moment at a funeral when one can expect to see grief expressed, though it only sometimes materializes. Partly this is allowed to persons who are not fully mature, not, that is, fully in possession of themselves and not-the same thing in Javanese thought--full masters of Javanese language. For them it is considered a leave taking; "the final goodbye," one man told me. But also, at that moment the deceased person is defined as 'dead,' by virtue of which he can control blessings. To treat him as belonging to the realm of death means to receive

6. Geertz, "Ritual and Social Change," p. 157.

7. At this point it is necessary to add a note about differences in funerals according to the gender and status of the deceased. The purpose of the funeral in all cases is to have the spirit of the person depart. If titles are available for use, then they add to the impression that only the relatively permanent attributes of the person are left in the visible world. The arwah or roh is not, however, completely lost. It is still somewhere else in the invisible world of spirits. As we saw in our example, when a prominent woman died she was treated as a man would also have been: she was eulogized in terms of her titles. In addition, however, as in all cases, there were prayers that called for the arwah or roh to be quickly "received" by God, leaving the corpse as a sign that the soul was, really, elsewhere. This is the central point of all funerals I witnessed, regardless of the sex or status of the deceased. 
blessings in return. Passing out of life, he becomes fixed in the mind as 'dead' and simultaneously the source of all that is good in life.

Pangèstu, blessings, that which he facilitates, refer to everything desirable that one might get in the course of one's life; a family of one's own, money, good marks on an examination, and so on. People seek pangèstu in graveyards, going on Thursday nights to graves reputed to be the abode of powerful spirits and, at least annually, to the graves of ancestors. In this sense pangèstu means not merely blessings but, when one seeks them, wishes. The deceased becomes the focus for wishfulness. The replacement of the memory of the person alive by the image or idea of him dead is fostered by the possibility of good things for oneself when the transfer is made. It is as though each resurgent memory of any deceased person would lead not to dismay at the loss but to confidence in oneself, so long as one could be sure the person really was 'dead.'

We can deepen our understanding of the role of imagery in Javanese ways of establishing 'death' by comparison. Javanese do not grieve in the sense that Freud described in "Mourning and Melancholia." 8 Freud thought of grieving as a form of "reality testing" which "shows that the loved one no longer exists." It "requires that all the libido shall be withdrawn from its attachment to this object. . . . Each single one of these memories and hopes which bound the libido to the object is brought up and hypercathected, and the detachment of the libido from it is accomplished." Freud does not elaborate on the process. The relinquishing of the deceased in the memory of the bereaved is a question of thinking memories once again. Freud does not say that the second revises the first. It seems to be an identical account of the event remembered, the image of the first. By remembering a second time, it is possible to attach oneself to (hypercathect) the second memory, and relinquish the first. The second account establishes the memory qua memory or image, set apart therefore from any association with the content of other thoughts.

This recourse to imagery establishes the person as image, not reality, therefore as 'dead.' The assumption of this reality testing is that the second remembering. the imaging of the first memory, is an encapsulation. Remembered the second time, the original memory is inscribed in an image which, after comparison, is set off from one's "hopes." Imagery becomes a form of mechanical memory: memory set off from the rest of one's thoughts. Javanese practice differs on the first count, but not the second. The encapsulation of the memory of the dead person, the removal of the person from one's hopes, plans, and memories, seems to happen without reality testing.

What Freud called the work of mourning takes a long time, and he could not explain why. Part of the answer is that Westerners who grieve do not want to give up the deceased for dead. Javanese feel the same way, but they are aided by thoughts of blessings, by the different status of the 'dead' in their thought. Still, this does not fully account for the absence of the work of mourning. There are two contradictory wishes: for the person to be alive, and for him to be dead. The early resolution in favor of one over the other needs more explication.

Another reason has to do with the role that imagery of the 'dead' plays in Javanese society. The corpse itself is a model of appropriate facial expression. The Western humanist notion of expression of character in facial expression involves thinking that disparate features are held together by a conscious, experiencing

8. Published in English translation in Sigmund Freud, General Psychological Theory (New York: Collier Books, 1963), pp. 164-80. (Originally published in 1917.) 
mind. The life in someone's face depends on the degree of tension and flexibility in the features; as though they could move, but could also move out of control. 9 In Java, the ideal face is round and rather fleshy. ${ }^{10}$ Roundness and fleshiness bring with them a good deal of inanimate space between the features. The result is neither tension nor relaxation, but an expression that seems not to try to impress. It is marked by the tenselessness that one finds also in the faces of corpses. If one examines the photo albums of funerals, one finds pictures of family and neighbors gathered around the open coffin. In such photographs the similarity of the corpse's expression to those of the spectators is evident.

The expression, however, is the same one Solonese put on whenever they expect their photographs to be taken. The similarity of facial expression thus might be due to imitation, or it might be coincidence. If it is imitation, it would proceed from the guilt felt at death; from the feeling that one should be more like the deceased.

Posing for one's picture, presenting one's best side, one pretends to a certain perfection whose model is the person freed from speech. What is imagined is not silence, which might, perhaps, be the place where speech would originate. It is, rather, freedom from the pressure that would dislocate one from one's social position. The attractiveness of the corpse is precisely that he or she cannot speak. Deceased persons are freed from the pressures that result in slips of good speech, marring perfect behavior. By looking like a corpse one puts oneself in its place. It is the corpse who is the most honored person in Solonese society, partly because the corpse is without the impulses that disrupt behavior; he thus fulfills a Javanese ideal. His position is indisputable and can be marred only by unwanted memories of him still alive. ${ }^{11}$

To those without knowledge of the Javanese language such a proposition may seem bizarre. However, in the context of Javanese speech levels it is reasonable. Javanese is two languages. One speaks high Javanese, Kromo, to those superior or sometimes equal in status. One speaks low Javanese, Ngoko, to children and others with no claim to respect. To one's inferiors one speaks middle Javanese, mostly a mixture of high and low Javanese, varying the amounts of each, depending on the degree of difference of status the speakers perceive between them. To those considered "intimate," such as one's spouse, one speaks low Javanese and is answered in kind. High Javanese is a second language, one learned after low Javanese, and one that most Javanese consider difficult to learn, to the point, often, of feeling that they have inadequately mastered it. To make a linguistic mistake, to use a low form where a high form is called for, is also to behave improperly.

9. See, for example, Georg Simmel, "The Aesthetic Significance of the Face," in Georg Simmel, ed. Kurt Wolff (Columbus: Ohio State University Press, 1959), pp. 276-81. (Originally published in 1917.)

10. On the historical background to this, see F. D. K. Bosch, The Golden Germ (The Hague: Mouton, 1960), who traces the "soft" features of even "ruthless slayers of enemies" in plastic representation to lotus-symbolism (pp. 220ff.).

11. Compare this statement made to Clifford Geertz that "it is a good thing to be dead. He spoke happily, not in any weltschmerz mood. I asked why he thought this, and he said, 'Well, when you are dead, you don't want anything: you don't want an auto, you don't want money, you don't want a wife, you don't have any wants at all. Like God--God doesn't need any money, or wife, or auto, does He? Well, that's wonderful, not to want anything; and after you're dead, that's the way it is." Religion of Java, p. 75. 
Moreover, high Javanese is not thought of as originating in the person of the speaker. It is talked about as though it were a property of the world. To learn it is to learn the nature of the world; to show that one knows the "right" names for things and the modes of address that somehow inhere in the person to whom one speaks. By contrast, low Javanese is what people speak naturally, without training. High Javanese, originating in the world, reflects it as it is, or, rather, as it is when it is named properly. It is not considered identical to one's intentions, as is low Javanese, or, even, to the world itself; it is merely the world embodied in speech. It thus is always secondary; a second language which, always being thought of as language and not referent, exists by its dependency on the world. It reflects the world, it is the image of the world in language.

Being assumed to be inherent in the world, and not in the speaker, high Javanese is recognized not only by its content or its forms, but also by knowing that one has given up something to get to it. It is the feeling that one is not speaking the language that one would speak naturally, low Javanese, that assures speakers that Kromo comes from the world and not from themselves. One thus leaves one's Ngoko-speaking self behind in speaking Kromo but generates a sign of its absence. Correct form becomes a sign of suppressed impulses.

The corpse, of course, cannot speak at all in either high or low Javanese. It nevertheless becomes an image of proper speech because it refers to a realm of potential disruption which exists apart from it. The corpse is 'dead, ' which in Javanese usage means that the roh, or soul, or spirit, is separated from it, It is usually through the mediation of the roh that blessings are said to return to the living. There is also a gamut of spirits called by various names such as jim. ${ }^{12}$ Though they are seldom identified with named persons, they are described as the energies of people continuing after their deaths. Under ordinary conditions these spirits are invisible. As they are invisible, the corpse cannot be identified with them. The corpse is simply their visible sign. That the corpse is so highly honored is in part because the terms of this separation allow the disruption of the spirits to be conflated with the disruptions of low Javanese. Unlike the person who carries the source of disruption within himself, the corpse is separated from it. The tenseless expression of the corpse is taken as the mark of someone no longer disturbed by the potential outbursts that prevent a living person from behaving (that is, speaking) as he or she should. The corpse thus looks the way one who is a perfect master of high Javanese should look.

One can try to look like the corpse, to take on the configuration of his or her facial features, which means to borrow that expression as an indication of something else, of the inability to be socially inept. The lack of expressiveness in corpses' faces, as is also the case in Kromo usage, does not, ideally, result from a struggle against expression. Rather it is all sign: it should reflect not what goes on interiorly, but what has been taken on properly, what does not originate in oneself and, precisely for that reason, is "proper." Thus, to imitate the dead does not imply an agent, an imitator, identical to the low Javanese speaker, who controls the imitation. What would be the agent is simply left behind. Furthermore, it is perfectly safe to look like the 'dead' because the 'dead' themselves cannot be equated with their attributes. They, too, are somewhere else. In taking on the aspect of the corpse, therefore, one is not exactly in the position of the 'dead, ' who, in their active form, are separated from any thing visible. ${ }^{13}$

12. For a description of these spirits, see ibid., pp. 26-29. Arwah is sometimes used to mean "life spirit."

13. There is a certain confirmation of this in the common warning of those with 
Javanese believe one's death is predetermined and one cannot know the time of its occurrence. 'Death' is thus removed from experience. It is not the natural end of biological development, thought to coincide with an arc of experience, but merely that which ends biological existence at any stage. It is, in this conception, another form of accident. But when one can accede to the signs of 'death, 'death' is reintroduced into social life as a regular feature. Conflated with proper social form, it becomes the basis for the social order itself. The disjunctive quality of speech levels, the quick changes in tone as a speaker moves from one to the other and then back again, are wholly congruent with another kind of integration, one in which 'life' and 'death' alternate. ${ }^{14}$

One pays respect to those who are most capable of themselves mastering high Javanese. Those who, ideally, look as though they are not bothered by an unwanted intrusion of low Javanese. The exaction required by hierarchy is that one should not speak one's "own" language when one addresses a superior but should substitute for it high Javanese. In speaking high Javanese, one is, thus, separating out one's own thoughts in favor of a certain image. If, following a death, Javanese more quickly resort to imagery to establish a line between life and death than Westerners, it is because they have already done so before the death occurred.

It is not a system that always works, however. By June of 1981 all of the corpses in the municipal cemeteries of Solo had to be moved outside the city limits, the land being reappropriated for other uses. Generally this meant holding a selamatan, a ritual feast, to appease the spirits before the transfer of the bodies. Families began to move their deceased relatives in February of 1981. Rather than being a time of tension, the process went on rather like a quiet picnic; those in the neighborhood would come by to watch as the bones were dug up and laid in new caskets. One could see, for instance, a man arranging the bones of his father, with no apparent intensity of feeling. The exception, however, was when the flesh of the corpse had not completely decayed. Laborers were ordinarily paid Rp. 1,000 or Rp. 1,200 for moving the body. This was a wage only slightly above the usual rate for daily labor in Solo. If, however, an odor was still emanating from the corpse, the wage climbed to $\mathrm{Rp} .25,000$. This meant about $\$ 40.00$ for a day's work, an unheard-of sum for a laborer. The reason was, to Solonese, obvious. If one smelled the corpse, one could oneself die. The contagion of death, that no one seems to feel in a Javanese funeral, became evident in these incidents.

Indeed, the smell of a corpse is said to be overwhelming. "If the body of a mouse stinks, how much more so the body of a man. It is unbearable [ora tahan]," one man told me when $I$ asked why laborers were paid so much to move rotting

magical powers that no one can take their photograph without their permission. Should anyone try, the film will be blank. Such powers are obtained from the realm of the dead; they are an intrusion of the powers associated with spirits into everyday life. But when they are operative they leave no trace. By the same logic, the corpse, being visible, is set apart from the active powers of the dead.

14. At this point, one might ask how it is that, if Javanese imitate the 'dead' and find it desirable to do so, they also expect blessings from them. Does not the expectation of blessings imply a difference which it would be in their interest to exaggerate? A complete answer involves a longer explanation of the place of deference in Javanese life than I can undertake here, and again involves speech levels. It is not the speaker of Kromo who goes out of existence when he or she dies; it is the speaker of Ngoko. It is the speaker of Ngoko who "exists," and who can die, and who receives the blessings of the dead. 
corpses. No matter how strong and unpleasant the stench might be, there is no obvious reason to think it will kill you; this, nonetheless, was the opinion of all the numerous people I asked about this matter.

Death is contagious for Surakartans when the corpse is smelled, when the odor of the corpse indicates its decay. When the corpse is thought to have changed state it can no longer be thought of as an unchanging image, as portrayed in the funeral photograph. The corpse is then like a living person in a photograph: before and after one sees it, it was and will be different. If it can change state, one has to think about it as one thinks about a person in an ordinary photograph; what, exactly, happened before one saw it, and what will (or, in the case of photographs, did) happen next.

Once one begins to wonder about the corpse, it becomes connected to the rest of one's thoughts, functioning in them as a live person would. The single thought that should be attached to it, that it belongs to the realm of the dead and is a potential source of pangèstu, or, minimally, that it is at least appeasable as Javanese spirits are, is put aside. There is no limit to what one could think about it after that. There is no way to separate it from any thought one might have. The link between life and death, between oneself here on one side and the corpse on the other, has been obscured. If there is no decisive difference between the living and the dead, death is already contagious. One could die smelling a corpse.

Nonetheless, since I have claimed that Javanese identify with corpses, this would not necessarily be undesirable. What make it so is that the identification cannot be with the corpse as it exists in high Javanese usage, as an image. This is in part due to the nature of odor. Smell is not easily mastered. One can refuse to touch or taste something more easily than one can block a smell, for instance. Moreover, odor has a closer connection to experience than sight or sound. What we recognize through sight or sound we might have seen in a picture, or heard on a recording, or have had told to us. Odors, however, are not reproducible; there is no equivalent of printed odors, and they are generally thought to be indescribable. The capacity to recognize a smell seems to depend on having smelled something like it before, rather than having learned about it some other way.

When one recognizes the smell of the corpse, it is unlikely that one does so on the basis of what one has been told of the way corpses smell. The particular odor is as weakly describable as any. One can know that the smell of the corpse emanates from it, and recognize it in that way. But if that were all that were involved, it would not evoke terror as it does. The terror is, in the first place, the result of not being able to appeal to idealized notions; of not being able to compare what one smells with what one "knows," and so lock the odor in place. To establish that the odor emanates from the corpse is not to recognize it completely. One can do that only by searching one's memory for previous experiences of smelling corpses. The problem comes not with recognition as such, but with recognition that depends on experience, rather than on what one has been taught. And it is compounded when "recognition" refers to memory, and one has had no experience. It is then uncanny.

Even when it is short of the uncanny, however, it still is not a desirable identification with the 'dead.' The 'dead' are those who are immune to the irruption of their "own" thoughts or their "own" language; one owes them the equivalent behavior. Seeing the corpse, the viewer should be able to suppress his own thoughts, in turn, as he recognizes it in terms of the high Javanese language it deserves. But odor prevents such recourse. It has no high Javanese equivalent because, as we have seen, it is not amenable to becoming a recognized sign. Odor appeals, then, to one's experience, to what one has learned without being taught. It sets 
aside whatever one has been taught, and opens the possibility of filling one's mind with unrecognizable thoughts. The odor of the corpse thus inaugurates the process which it would be the role of the idealized corpse, or the corpse as image, to stop.

This must be put into the context of hierarchy. One might ask what the gain is in deferring; why it is that anyone would want to speak high Javanese. There are two answers to this question that are important to us. The first is that, to speak high Javanese establishes one's social position, and wins one esteem, in a way that speaking low Javanese does not. To speak low Javanese to someone who defers to one in high Javanese does not establish one's social place. The confirmation one wins from someone one need not respect has little value. In deferring, on the other hand, one displays one's knowledge of the right names of the world. Mastery of high Javanese can be shown only in deferring. It is through such mastery that one shows oneself to be a person worthy of respect. Thus, for instance, higher status people are said to speak better high Javanese than villagers.

The second reason is more directly relevant to us. When one speaks Kromo, high Javanese, one keeps one's "natural" speech, low Javanese, to oneself. One does not say what immediately comes to mind. Ngoko, low Javanese, thus comes to stand for what one reserves to oneself, apart from hierarchy. The self that goes out of existence when one dies is the speaker of low Javanese. The speaker of high Javanese is, ideally, equated with the 'dead' even before his biological death. It is Ngoko, low Javanese, which, kept out of speech, keeps one on this side of a line between 'life' and 'death.' It is this self that is the object, for instance, of the blessings that cross that line from the 'dead' to the living.' The stimulation of odor threatens a limitless expression, and thus endangers the reserved self. It is the evacuation of this self, the effect of odor, that Javanese refer to when they say that, smelling the corpse, "one could die."

Most Javanese deny being afraid of 'death.' If we judge by those who prepare themselves by becoming like the corpse or by identification with corpses in everyday life, we can understand the basis for their statement. Within quotation marks, 'death' means being an image oneself and being devoid of the impulses that disrupt proper speech and behavior. The death that is thought to come with odor, however, is devoid of imagery and leaves disruptive impulses problematic in status. Hence the implicit acknowledgement of fear in the statement, "it could kill you."

Spirits frequently disrupt Javanese life. But spirits, by their identity as spirits, invisible beings, can be dealt with. Before the corpses were uncovered, many of their living relatives consulted soothsayers to determine if the spirits of the dead were still present in or near the graves. The purpose of the ritual feasts was, indeed, to appease these spirits wherever they might be.

The uncovered bones of the dead were themselves an assurance that the active 'dead, ' in the form of ghosts or spirits, were somewhere else. The very invisibility of these spirits was a guarantee that they need not be equated with the visible remains of the dead. This made it safe to pay the dead respect. It was, for instance, a gesture of respect to arrange the bones of an ancestor as they were uncovered. Doing so, the bones were not put into a mental series, beginning with the bones, perhaps running through the bones as corpse at the time of death, and continuing with the person as he was in life. Their reference, rather, was, like that of the initial corpse, to the active 'dead' apart from them. But the smell of the decaying corpses, setting off thoughts that the sight of the corpse should have suppressed, charged the decaying corpse with danger. When this happened, the 
danger could not be attributed to spirits who exist apart from the visible remains of the corpse.

Were the decaying corpses said to be infested with spirits, they could have been dealt with. On the face of it, it is surprising that no one resorted to such an explanation; it is the common recourse in Java. ${ }^{15}$ But once the corpse was charged with danger, it did not refer to a place somewhere else that could become the scene in which fears were embodied. It could not act as the sign which made displacement possible; displacement of the fear of disrupting speech into an invisible realm of spirits. The corpse, devoid of this reference, should have been just a dead body. Were it thought of that way, it would have been possible to speak of odor as the route of contaminating disease. While many Javanese I spoke with were quite capable of such explanation, no one thought about the smell in this way.

The corpse, charged with danger, functioned to stimulate a displacement without ever achieving it. Because it was the remnant of a once living person, it should have indicated 'death,' or taken on some new meaning. But it was devoid of life, and yet without the capacity to refer to death in any sense. Within the framework of Javanese hierarchical use of language, it should have evoked the proper restraint in those who viewed it. But without a notion of 'death' to which to appeal, without, that is, the corpse as image, it had the opposite effect.

Rather than restraint, that effect would have been the blurting out of whatever the corpse stirred in those who smelled it. I did not hear of this happening; but neither was I told of anyone actually killed by the odor. We might, however, ask more precisely about the effect. We can find an answer in the Javanese condition

15. The effect of funerals and the other celebrations that follow upon a death is to ensure that the roh is acceptable to God. But Javanese thought does not include any notion of a place where this acceptance is finally accomplished. Even the Christians of the conventional denominations--Catholic and Protestant--put little stress on this dimension of the afterlife, while the Islamic belief that the souls of the dead continue to exist till the last judgment coincides with traditional Javanese belief. Javanese live in the continual presence of the 'dead,' who take various forms. The question, then, is whether fear of the decaying corpse is not fear of the spirit which might be thought to be still in the vicinity. The most definitive answer I can give to the question is that, despite persistent questioning, no one attributed the death that comes with odor of the corpse to spirits. As I have said, those who had their relatives moved often believed that the roh was in the vicinity. But this was as true for fully decayed corpses as for more recent ones. Furthermore, the presence of a spirit is, in a way, almost reassuring; one can appease it simply enough.

What I have described is a fear that has no solution, and no reassuring effects. Wedi, the word for fear in Javanese, means also respect. The connection between the two concepts comes through speech. Someone who is fearful will speak high Javanese. (On wedi, see Hildred Geertz, The Javanese Family [Glencoe, III.: Free Press, 1961], pp. 111ff.) In speaking high Javanese, the speaker alleviates his fear by making it into a sign removed from himself. For example, Javanese intensely dislike being startled. They have an exclamation that they use not when they are startled, but in the places where, had they not spoken that word, they would be startled. By registering their 'fear' in what they consider a second language, Javanese avoid the stress of feeling it. The fear that was generated by thoughts of the odiferous corpse, however, escaped this possibility. It is, indeed, precisely this evasion of speech that is the topic of this paper. 
known as latah. According to anthropologist Hildred Geertz, "the symptoms of latah are an involuntary blurting out of obscene words or phrases, compulsive imitation of the words or actions of others, and compulsive unquestioning obedience when ordered to perform actions which may be ridiculous, improper, or even dangerous." 16 What interests us about latah is that it includes an irruption of crude speech when refined speech is called for; low Javanese in the place of high Javanese. Furthermore, latah occurs precisely in those areas of Java where people feel least secure in their control of high Javanese. It does not occur in the areas of Central Java whose inhabitants are known for having the best command of high Javanese (Surakarta and Yogyakarta). It thus is a condition (the Javanese do not consider it a disease) that occurs in situations such as the one 1 have been describing: it happens where recourse to high Javanese forms is not possible, and where one therefore simply comes out with what should be reserved.

What is actually said is frequently obscene. Hildred Geertz reports, for instance, that one woman offered someone a cup of tea with the words, "Please have some vagina." She also gives this incident:

. . . in one mild case, the latah was startled in the midst of a conversation about baskets. The Javanese word for basket resembles the word for horse, and the latah, meaning to say. "Hand me that basket there," cried out "Go have intercourse with a horse." .. ${ }^{17}$

What would have been blurted out in the presence of a decaying corpse might have been similar. It might have had any content. What matters is that, whatever it was that might be said, it should be kept to oneself.

The difference between such senseless blurtings and the figures of the spirits is marked. It is the difference between automatic speech, which says as little as speech can, and figural language. Without the displacement of fears the corpse provided, the means to figure these fears also disappeared. People thus spoke of the odor of the corpse as a way of saying that it assailed them with a barrage that both stimulated and refused sense. A barrage that could have aroused only latahlike reactions. Odor was not so much what people smelled or feared they might smell as an oblique reference to a point where language was upset.

Any odor has the capacity to stimulate memory and thus threaten the role of imagery in keeping memories of the dead apart from other thoughts. To guard against the unexpected stimulation of memory, Javanese use a special incense called menyan or kemenyan. When Javanese make offerings to the spirits, who, one remembers, are thought to be the remnants of once-living persons, or make offerings at graves, they burn incense. Their incense is different from the Chinese variety. The latter has a pleasant aroma. Menyan, however, is unpleasant to Javanese unless, as is only occasionally the case, honey is added to it. ${ }^{18}$ Incense, menyan, is called "food of the spirits." None of the numerous Javanese I asked liked the smell, unless it was of the variety that had honey added. Generally people would say that it made them afraid, since it was intended for jim or spirits. What is remarkable,

16. For latah, see Hildred Geertz, "Latah in Java: A Theoretical Paradox," Indonesia, 5 (April 1968), pp. 93-104.

17. Ibid., p. 94.

18. Javanese, indeed, have another kind of incense, ratus, which is sweet smelling. It is menyan, however, that is used for offerings. 
however, is that I could never elicit any associations connected with it. ${ }^{19}$ It is an odor that, rather than evoking memory seems to repress it, as indeed, the fear it stimulates might suggest.

Though it does not appear to be a widely known belief, one teacher of Javanese mysticism told me that menyan was designed originally to cover up the smell of the corpse. Its use, however, is not for that purpose today. Though used in funerals, it functions mainly in ceremonies connected with the dead who are already buried and out of sight. It does not suppress the odor of the corpse; it indirectly suppresses memory. Suppressing other smells, it guards against the associations that any odor can stimulate. The odor of menyan generates the sense, 'death,' in its Javanese meaning. One cannot escape the smell and, though it is unpleasant, one does not want to. The meaning, 'death,' replaces any particular memory that would otherwise surface. Menyan thus evades the general inability of smell to become a recognized sign.

Again, it does not always work. I have mentioned the two cases where it is least likely to work. Young people, those up through their middle teens whom one might see grieve at the trobosan, are one case. They do not yet have full access to imagery, being thought of as immature. The other case is mothers who have lost children. In my experience, it is particularly mothers who have lost older children who are vulnerable to grief. It is not only that they have a full store of memories to contend with, but also it is harder for them, too, to have recourse to imagery. Imagery implies blessings, and blessings should come from the senior to the junior, other aspects of status being equal. When children die before their mothers, the situation is reversed. Fathers, on the other hand, are more remote from their children and have less to cope with. Despite this caveat, however, it is my experience that most Javanese do not grieve even when they are most vulnerable.

I once visited an upperclass couple whose son had died in a motorbike accident a year earlier. The mother still occasionally was affected by memories of her son. Perhaps for that reason the father, though he kept a photograph of his son in the living room, kept it face down. As we were talking, a group of the son's friends, including his former fiancée, came to call. They talked about the boy, how he would have been a doctor by this time, how he had died, with no signs of grief. Then for my benefit, as I had not known the son, the father picked up his photograph and showed it to us. As the company left, the mother and fiancée were in tears. Face up all the time, the photo would have indicated the 'death' of the boy, the encapsulation of his memory apart from other thoughts. Unexpectedly revealed as it was, the photograph was not a static image but a sudden reappearance.

To affect his mother and his fiancée as it did, the photograph of the corpse must have awakened memories. It functioned as a souvenir, a reminder of past events and of the boy's absence. The decaying corpse, by contrast, threatened anyone who might chance to smell it, whether they had known the deceased person, and thus had memories of him, or not. The odor of the corpse did not stimulate associations with the person as he was alive. It stirred thoughts that could have had nothing to do with the experience of the deceased. It caused not grief but terror.

19. I am aware of how difficult it can be to elicit associations. I can only say that people who ordinarily spoke to me most unreservedly, who spoke to me in Ngoko and under circumstances that seemed propitious, denied having any associations evoked by the smell of menyan. 
These examples are unusual. Usually there is an immediate division of experience: images on one side, idiosyncratic memories on the other. There is no need for grief or mourning, and no sign in daily life of memories returning to disturb survivors. And there is little of the shock caused by odor. The living are iklas. But their detachment can vanish if the image comes to life, or when, with a random whiff, it is no longer an image.

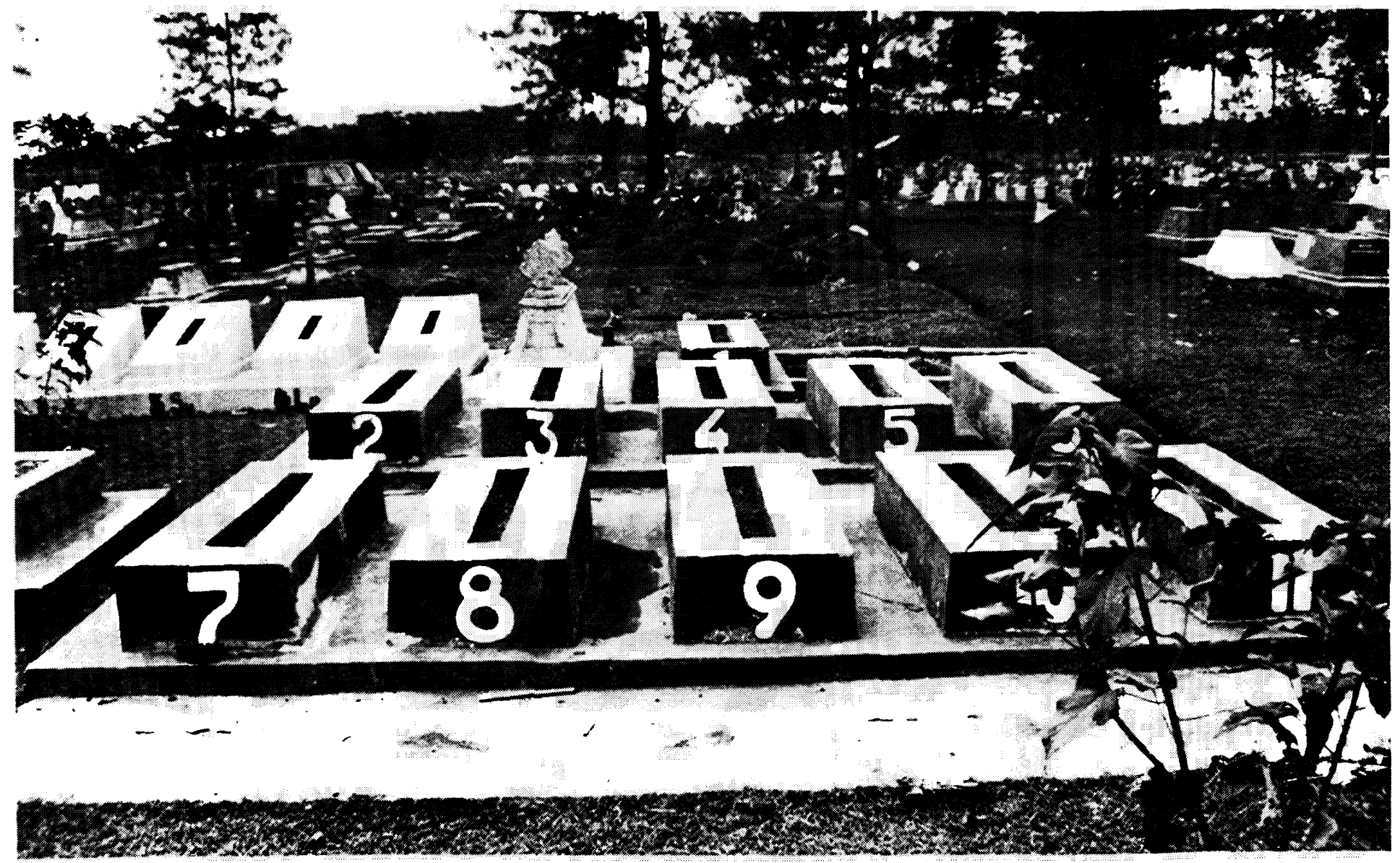

A new cemetery.

Photographs by Y. A. Yovovskii 